\title{
12 UPAYA PENANGANAN PEKERJA SEKSUAL ANAK
}

\author{
Oleh: \\ Puspa Sagara Asih, Hadiyanto A Rachim, \& Nandang Mulyana
}

\begin{abstract}
ABSTRAK
Perdagangan anak perempuan untuk tujuan pelacuran, merupakan praktek yang tidak berpihak pada anak-anak. Berbagai Stigma sosial, resiko penyakit Infeksi Menular Seksual (IMS), bahkan HIV/AIDS dan beberapa kenakalan remaja sangat rentan atas anak-anak yang dilacurkan. Selain bahaya akan penyakit IMS, anak yang masih belum stabil kondisi psikososialnya akan mengalami beberapa gangguan pada perkembangan psikis dan sosialnya. Pemerintah tidak hanya diam menanggapi isu ini, beberapa peraturan perlindungan dan program untuk mensejahterakan anak telah dibuat dan dijalani, namun belum mampu menekan maraknya perdagangan anak perempuan yang dilacurkan serta masih banyaknya praktek pelacuran anak terjadi. Bukan hanya pemerintah yang memiliki andil dalam menekan angka ESKA (Eksploitasi Seksual Komersial Anak), namun masyarakat juga memiliki andil dalam menekan angka jumlah ESKA. Berdasarkan beberapa jurnal ilmiah dan artikel yang telah penulis baca, menunjukkan bahwa aktor atau pelaku perdagangan anak ternyata seringkali juga dilakukan oleh orang dekat bahkan oleh kerabatnya sendiri termasuk oleh perempuan itu sendiri. Praktek perdagangan yang dilakukan oleh sesama perempuan, seringkali tersembunyi dengan berbagai dalih tanpa terlihat ada paksaan, yang justru menjadikan mereka korban. Sebagai profesi yang mendalami mengenai psikososial individu, pekerja sosial diharapkan mampu untuk membantu mengatasi ESKA melalui pendekatan, assessment serta metode-metode casework. Salah satu upaya yang dapat dilakukan oleh praktisi pekerja sosial dalam kasus ini adalah sebagai educator, fasilitator, enabler, broker dan advocator.
\end{abstract}

Kata Kunci: Pelacuran Anak, Eksploitasi Seksual Komersial Anak, Pekerjaan Sosial, Casework.

\section{PENDAHULUAN}

Fenomena human trafficking atau perdagangan manusia pada konteks anak belakangan ini marak dilakukan, anak-anak yang diperjual-belikan ini bukan hanya merambah pada sektor industri, pertanian, dan perkebunan saja tetapi juga sampai pada perdagangan anak dalam dunia pelacuran. Semakin hari fenomena anak yang dilacurkan semakin marak dilakukan dan memprihatinkan. Kotakota besar di Indonesia seperti Bandung, Jakarta, Surabaya, Medan dan Kota besar lainnya menjadi beberapa dari banyak kota-kota besar yang masih terdapat banyak sekali pelacur anak.

Pada kenyataan yang terjadi sekarang adalah jumlah anak yang menjadi Eksploitasi Seksual Komersial Anak (ESKA) semakin banyak dan jumlah penyebaran pun diperkirakan hanya bisa dihitung dipermukaan. Di Indonesia pada tahun 2010 tercatat 40.000 - 70.000 anak telah menjadi korban Eksploitasi Seksual Komersial Anak (ESKA). Mayoritas dari mereka dipaksa bekerja dalam perdagangan seks. Praktik-praktik tersebut terutama berlangsung di pusat prostitusi, tempat hiburan, karaoke, panti pijat, pusat perbelanjaan, dan lain-lain. Di Semarang, Yogya dan Surabaya, terdapat 3.408 anak korban pelacuran baik di lokalisasi, jalanan, tempat-tempat hiburan, dan panti pijat (ILOIPEC, 2010). Di Jawa Barat jumlah anak yang dilacurkan pada tahun 2010 sebanyak 9000 anak atau sekitar 30 persen dari total PSK 22.380 orang (Dinas Sosial, 2010). Mengacu kepada data Koalisi Nasional Penghapusan ESKA, ada 150.000 anak Indonesia dilacurkan dan diperdagangkan untuk 
tujuan seksual Data tersebut menunjukkan bahwa semakin maraknya tindak pidana seksual komersial anak.

Dapat dilihat bahwa angka anak yang terlibat dalam Eksploitasi Seksual Komersial Anak (ESKA) amat mencengangkan dan mengejutkan. Lebih dari 100.000 anak Indonesia diperjualbelikan dengan tujuan seksual. Kondisi ekonomi keluarga, kurangnya pengetahuan dan informasi, rendahnya tingkat pendidikan serta masih rendahnya upaya perlindungan anak merupakan beberapa faktor yang menyebabkan anak terjerumus ke dalam pelacuran anak tersebut.

\section{PEMBAHASAN}

Data mengenai anak yang menjadi korban Eksploitasi Seksual Komersial di Indonesia pada tahun 2010 tercatat 40.000 - 70.000. Mayoritas dari mereka dipaksa bekerja dalam perdagangan seks. Praktik-praktik tersebut terutama berlangsung di pusat prostitusi, tempat hiburan, karaoke, panti pijat, pusat perbelanjaan, dan lain-lain. Di Semarang, Yogya dan Surabaya, terdapat 3.408 anak korban pelacuran baik di lokalisasi, jalanan, tempat-tempat hiburan, dan panti pijat (ILO-IPEC, 2010). Di Jawa Barat jumlah anak yang dilacurkan pada tahun 2010 sebanyak 9000 anak atau sekitar 30 persen dari total PSK 22.380 orang (Dinas Sosial, 2010).

KAP Indonesia mengungkapkan bahwa hal yang paling mengejutkan adalah banyaknya anakanak sekolah yang telah terjerumus dengan ESKA dan terlibat transaksi seks. Faktor penyebab bukan hanya faktor kemiskinan dan ekonomi saja, tetapi sekarang beralih kepada faktor kedekatan, kenyamanan, keamanan dan gaya hidup hedonisme. Hubungan kuat lain antara perilaku seksual remaja sekolah dengan dunia pendidikan adalah alasan yang digunakan para pelajar siswi masuk ke dalam seks komersial, walaupun imbalan yang mereka dapat tidak begitu besar. Teman yang diajak atau dilibatkan ke dunia seksual juga masih mempunyai kedekatan hubungan emosional yang diikat oleh kenyataan bersekolah di sekolah yang sama atau teman satu geng atau kelompok. Modus operasi yang digunakan dalam menjebak anak-anak masuk ke dalam dunia pelacuran, umumnya diajak oleh teman yang lebih dahulu masuk ke dunia ini, lalu diperkenalkan dengan tamu. Dapat diprediksi selanjutnya anak-anak mencari tamu sendiri dengan cara ke diskotik, atau langsung menghubungi tamu tersebut. Situasi-situasi di atas seringkali menjadi situasi yang membahayakan bagi anak untuk hadir dalam situasi seks eksploitasi seks komersial. Sehingga beberapa kasus ditemukan anak berada dalam situasi krisis yang mengharuskan anak keluar dari situasi tersebut.

Pada sebuah blog dengan domain http://saveIndonesianchildren. wordpress.com memuat kasus yang dialami Mawar usia 16 tahun. Mawar, akan genap 16 tahun pada bulan September nanti. Rela menjual diri untuk melayani nafsu om-om karena desakkan ekonomi. "Biaya pendidikan mahal, biaya hidup mahal, mau bekerja yang benar saya masih sekolah, sedangkan kebutuhan hidup tidak bisa menunggu. Mana pemerintah menaikkan harga BBM" demikian kilahnya. Dari data yang ada diperkirakan, $30 \%$ pelacur atau pekerja seks komersial di Indonesia dijalani oleh anak-anak dibawah umur dan dibawah 18 tahun.

Kekhawatiran dan keprihatinan mengenai permasalahan ESKA yang telah dikemukakan di atas menggugah untuk melakukan kegiatan untuk menyelesaikan permasalahan eksploitasi seks komersial anak dikalangan remaja dengan memperhatikan kecenderungan pergaulan remaja yang mengarah kepada perilaku seks komersial dikalangan anak disekolah. Apalagi peralihan masa kanakkanak menuju remaja adalah masa-masa yang sangat riskan terhadap perubahan. Hurlock (1980 : 206-207) juga mengungkapkan bahwa

"Masa remaja adalah periode penting, peralihan dan perubahan. Dimana masa remaja akan dimulai dari perubahan fisik yang cepat dengan disertai perubahan mental yang cepat pula. Perubahan tersebut mempengaruhi tingkah laku individu dan mengakibatkan penyesuaian nilai-nilai yang bergeser. Perubahan-perubahan yang terjadi tidak hanya terjadi secara fisik saja, tetapi berakibat pada perubahan emosi, minat, peran, pola perilaku dan nilai-nilai”. 
Beberapa anak yang terjerumus kedalam pelacuran ini tidak hanya karena desakan ekonomi saja, namun ada beberapa diantara mereka yang terjebak dalam pelacuran karena pengaruh lingkungan. Penulis menganalisa bahwa seorang anak yang tidak mendapatkan pengakuan dan kurang akan rasa kasih sayang serta kelekatan dengan orangtuanya dapat berpotensi untuk mencari apa yang dia butuhkan di tempat lain yang mungkin akan berdampak buruk kedepannya. Lisa (bukan nama sebenarnya) adalah salah satu contoh remaja yang terjerumus ke dalam dunia pelacuran bukan karena kondisi ekonomi yang lemah serta rendahnya tingkat pendidikan.

Lisa (16 tahun) menjadi pelacur di samping statusnya sebagai seorang pelajar di kelas dua sebuah SMA favorit di Medan, karena pergaulan modern yang salah kaprah. Menurutnya ia menjadi pelacur karena pergaulannya dengan seorang pria ganteng bermobil kijang yang juga mahasiswa perguruan tinggi swasta di Medan. Pergaulan Lisa dengan sang pacar akhirnya menjadi sebuah hubungan yang lebih dalam. Lisa menyerahkan kegadisannya pada sang pacar, saat itu ia lagi "on" (istilah mengalami halusinasi akibat obat terlarang).

Namun belakang, sang pacar yang akhirnya pindah ke luar Sumatera dan harus berpisah dengan Lisa. Kondisi ini ternyata memperburuk kehidupannya. Selain ia kehilangan tempat untuk mencurahkan rasa rindu, ia juga telah mencapai kondisi rawan dalam penggunaan obat terlarang. Tadinya, hal ini masih dapat ditanggulanginya dengan menghabiskan uang buku, uang sekolah, dan uang-uang lain yang ia minta dari orang tuanya. Tapi semua itu tidaklah berlangsung lama. Setelah mendapat beberapa surat teguran dari pihak sekolah akhirnya ia harus mengalami peraturan uang ketat, dimana orang tua tidak lagi memberikan uang secara berlebihan tetapi lebih teratur sedemikian rupa hingga hanya cukup untuk kebutuhan seorang remaja kota biasa.

Kondisi Lisa yang demikian mengharuskannya untuk mencari uang lebih untuk memberi beberapa butir pil setan demi khayalannya. Dan itu bukanlah pekerjaan yang mudah bagi seorang gadis yang duduk di bangku sekolah. Jalan akhir yang dia tempuh setelah berkonsultasi dengan temannya adalah dengan mencoba mendekati para Om-om senang atau para eksekutif muda yang biasa mereka jumpai di pusat-pusat hiburan. Dan demi beberapa butir pil akhirnya Lisa telah menjerumuskan diri ke dalam dunia pelacuran.

(Sumber: http://sosbud.kompasiana.com/2010/03/23/bisnis-pelacuran-anak-ahmad-sofianpkpa-100740.html diakses pada tanggal 11 Desember 2014 Pukul 23.53)

Kasus yang ditampilkan di atas menunjukkan bahwa pelacuran anak tidak hanya menjadi bisnis para mucikari seperti yang selama ini nampak ke permukaan, tetapi juga karena kondisi psikologi, sosial, kultural, dan ekonomi keluarga.

Tahap perkembangan Lisa (16 Tahun) menurut Erickson masuk kedalam tahapan Adolesence (remaja), yang dimulai pada saat masa puber dan berakhir pada usia 18 atau 20 tahun. Masa Remaja (adolescence) ditandai adanya kecenderungan Identity - Identity Confusion. Sebagai persiapan ke arah kedewasaan didukung pula oleh kemampuan dan kecakapan-kecakapan yang dimilikinya dia berusaha untuk membentuk dan memperlihatkan identitas diri, ciri-ciri yang khas dari dirinya. Dorongan membentuk dan memperlihatkan identitas diri ini, pada para remaja sering sekali sangat ekstrim dan berlebihan, sehingga tidak jarang dipandang oleh lingkungannya sebagai penyimpangan atau kenakalan. Dorongan pembentukan identitas diri yang kuat di satu pihak, sering diimbangi oleh rasa setia kawan dan toleransi yang besar terhadap kelompok sebayanya.

Dalam kasus Lisa, trend yang sedang popular di kalangan anak remaja seusianya adalah memiliki pacar atau teman lelaki yang tampan, kaya, memiliki kendaraan, serta seorang mahasiswa. Sehingga pada saat lelaki dengan tipe tersebut mendekatinya, dia menyambut dengan baik karena Lisa butuh pengakuan dari teman-teman sebayanya. 
Setiap perubahan dan peralihan pada remaja seringkali menjadi faktor pemicu mereka terjebak dalam situasi yang sebenarnya tidak menguntungkan mereka sendiri seperti terjebak dalam situasi eksploitasi seks komersial anak (ESKA). Sehingga semua pengambilan keputusan seringkali terkesan terburu-buru tanpa difikirkan lebih dahulu, akibatnya mereka seringkali menyesal diakhirnya

\section{Pekerjaan Sosial}

Pekerjaan sosial adalah sebuah aktivitas profesional yang membantu proses pelayanan pemecahan masalah terhadap permasalahan baik individu, kelompok ataupun masarakat. Pekerja sosial membantu memahami kondisi dan kenyataan-kenyataan yang mereka hadapi serta memberikan pilihan-pilihan guna membantu menyelesaikan masalah. Kaitanya dengan masalah ESKA pekerja sosial juga menghubungkan aspek yang telah didapat dalam asesmen dengan sistem ekologis, guna melihat hubungan atau keterkaitan masalah sehingga memberikan intervensi yang tepat terhadap penyelesaian masalah.

Pekerja sosial dalam pekerjaannya memberikan pelayanan sosial baik kepada individu, kelompok maupun masyarakat yang membutuhkan sesuai dengan nilai-nilai pengetahuan dan keterampilan profesional pekerja sosial. Fokusnya adalah meningkatkan keberfungsian sosial (sosial function) melalui intervensi yang bertujuan atau bermakna. Keberfungsian sosial merupakan konsepsi penting bagi pekerjaan sosial. Ini merupakan pembeda antar pekerjaan sosial dan profesi lainnya.

Fungsi pekerja sosial yang dijelaskan oleh Heru Sokoco (1995:22-27) yang berdasarkan dengan kasus pelacuran yang telah penulis uraikan yaitu pekerja sosial membantu meningkatkan dan menggunakan potensi yang ada pada anak yang menjadi korban pelacuran untuk melaksanakan tugas kehidupan sosial dan memecahkan masalah sosialnya. Pekerja sosial juga memiliki fungsi untuk menghubungkan dan memfasilitasi anak korban pelacuran dengan sistem-sistem sumber yang dapat membantu anak korban pelacuran menemukan system sumber yang dapat membantu mereka keluar dari masalahnya seperti lembaga perlindungan anak dan perempuan serta departemen sosial. Selain itu pula, pekerja sosial memiliki fungsi sebagai agen perubahan (agent of social change) dimana pekerja sosial mengusulkan dan mempengaruhi kebijakan-kebijakan sosial dalam kasus pelacuran.

Berdasarkan peranan pekerja sosial yang disebutkan oleh Heru Sukoco, dalam kasus pelacuran anak ini pekerja sosial memiliki peran yang sangat penting dalam pengembangan potensi anak-anak korban pelacuran. Dalam konteks anak yang dilacurkan ini, Pekerja sosial memiliki peranan sebagai enabler dimana pekerja sosial membantu anak yang dilacurkan dalam mengakses sistem sumber perlindungan anak yang ada seperti lembaga-lembaga yang concern dengan masalah prostitusi anak, mengidentifikasi masalah dan mengembangkan kapasitasnya agar dapat mengatasi masalah sehingga dapat menemukan solusi dalam penanganan masalah tersebut, selain itu juga pekerja sosial sebagai broker yaitu dimana pekerja sosial menghubungkan anak yang dilacurkan dengan lembaga pemberi pelayanan masyarakat seperti perlindungan anak dan lembaga-lembaga non-profit yang memperjuangkan kesejahteraan anak. Dan yang terakhir adalah pekerja sosial dalam kasus anak yang dilacurkan ini berperan sebagai Fasilitator dimana pekerja sosial menstimulasi dan mendukung perubahan anak kearah yang lebih baik.

\section{Upaya Pemerintah dalam Menangani Masalah Pekerja Sosial Anak}

Saat ini penanganan mengenai isu anak oleh pemerintah sudah dapat dibilang cukup baik. Dengan dibuatnya PKSA (Program Kesejahteraan Sosial Anak) dan dibuatnya Undang-Undang Perlindungan anak nomor 23 Tahun 2002 dimana dalam UU tersebut membahas mengenai hak-hak anak yang mengacu pada Konvensi Perlindungan Anak.

Dalam UU No 23 Tahun 2002 ditulis dalam BAB I mengenai Ketentuan Umum, Pasal 1 Ayat 15 mengenai perlindungan khusus, dimana perlindungan khusus adalah perlindungan yang diberikan kepada anak dalam situasi darurat, anak yang berhadapan dengan hukum, anak dari kelompok minoritas dan terisolasi, anak yang dieksploitasi secara ekonomi dan/atau seksual, anak yang 
diperdagangkan, anak yang menjadi korban penyalahgunaan narkotika, alkohol, psikotropika, dan zat adiktif lainnya (napza), anak korban penculikan, penjualan, perdagangan, anak korban kekerasan baik fisik dan/atau mental, anak yang menyandang cacat, dan anak korban perlakuan salah dan penelantaran.

Dapat dilihat dari penjelasan UU diatas bahwa anak yang dilacurkan atau dieskploitasi secara seksual mendapatkan perlindungan khusus yang diatur oleh pemerintah dan lembaga Negara. Yang dilakukan melalui: penyebarluasan dan/atau sosialisasi ketentuan peraturan perundang-undangan yang berkaitan dengan perlindungan anak yang dieksploitasi secara ekonomi dan/atau seksual; pemantauan, pelaporan, dan pemberian sanksi; dan pelibatan berbagai instansi pemerintah, perusahaan, serikat pekerja, lembaga swadaya masyarakat, dan masyarakat dalam penghapusan eksploitasi terhadap anak secara ekonomi dan/atau seksual.

Kurangnya informasi akan mengenai pengaduan atau pelayanan guna mengurangi perdagangan anak khususnya dalam perdagangan seksual anak ini juga membuat masyarakat kurang paham mengenai ESKA (Eksploitasi Seksual Komersial Anak). Seharusnya pemerintah memberikan informasi kepada masyarakat secara menyeluruh hingga sampai ke pedesaan melalui penyuluhan atau sosialisasi. Sehingga masyarakat pedesaan bisa memahami masalah ini dan ikut berpartisipasi dalam mengurangi angka perdagangan seksual anak.

\section{Upaya Penanganan Lembaga Non-Profit dalam Menangani Pekerja Seksual Anak}

Bukan hanya lembaga pemerintahan saja yang ikut berpartisipasi dalam membantu mengurangi angka ESKA (Eksploitasi Seksual Komersial Anak), tapi juga beberapa lembaga-lembaga non-profit serta masyarakat yang peduli akan anak. Salah satu contoh lembaga non-profit yang ikut membantu dalam mengurangi perdagangan seksual ini adalah ECPAT.

ECPAT (End Child Prostitution, Child Pornography \& Trafficking of Children for Sexual Purposes) Indonesia adalah sebuah organisasi jaringan nasional yang bekerja bersama di lebih dari 20 organisasi di 11 propinsi di Indonesia untuk menentang Eksploitassi Seksual Komersial Anak (ESKA), meliputi perdagangan seks anak, pelacuran anak, pornografi anak, pariwisata seks anak serta dalam beberapa hal perkawinan anak.

ECPAT Indonesia berkomitmen untuk memperkuat aksi nasional dalam upaya mencegah dan menghapuskan ESKA di Indonesia dengan membangun kolaborasi bersama pihak-pihak kunci lintas sektor seperti organisasi masyarakat sipil, akademisi, badan pemerintah, sektor swasta, badan internasional dan sektor-sektor relevan lainnya. Kehadiran kami adalah untuk memastikan semua elemen masyarakat khususnya pemerintah melakukan langkah-langkah serius dan sungguh-sungguh dalam menangani kejahatan ini.

ECPAT Indonesia merupakan bagian dari ECPAT Internasional, yaitu sebuah jaringan global yang bekerja untuk menentang ESKA dengan lebih dari 84 grup di lebih dari 75 negara di seluruh dunia. Sebagai bagian dari jaringan global, ECPAT Indonesia terlibat dalam pelaksanaan berbagai inisiatif pada isu-isu kunci baik di tingkat nasional maupun regional. Keterlibatan ECPAT Indonesia harus diikuti oleh anggota di tingkat propinsi atas nama jaringan nasional.

Tujuan berdirinya lembaga non-profit ECPAT Indonesia ini adalah agar setiap anak Indonesia bebas dan terlindungi dari segala bentuk eksploitasi seksual komersial dan terpenuhinya hak mendasar anak yang dijamin oleh segenap masyarakat dan pemerintah. Sehingga Kesejahteraan Sosial Anak dapat terwujud. Hal-hal yang dilakukan oleh ECPAT Indonesia agar tercapainya tujuan dibentuknya lembaga ini adalah:

- Advokasi kepada pemerintah dan pihak-pihak kunci di tingkat nasional dan propinsi terkait kebijakan, peraturan dan perbaikan hukum untuk memperkuat rencana aksi nasional untuk penghapusan ESKA

- Penguatan kapasitas anggota dan kelompok strategis terkait tentang ESKA melalui dukungan teknis, pelatihan dan lokakarya 
- Pengumpulan data tentang situasi ESKA melalui serangkaian survey, penjajakan cepat dan penelitian

- Penyebarluasan informasi tentang ESKA melalui sosialisasi, seminar, diskusi dan konfrensi

- Peningkatan kesadaran masyarakat tentang ESKA melalui pengembangan material kampanye dan media komunikasi

- Promosi program partisipasi anak dan orang muda menentang ESKA melalui pembentukan kelompok pemuda dan pengembangan program berbasis komunitas untuk pencegahan

- Pelayanan dan dukungan untuk anak korban dan penyintas ESKA melalui program layanan langsung meliputi penyelamatan, pemulangan, rehabilitasi, reintegrasi dan pemberdayaan.

\section{KESIMPULAN DAN REKOMENDASI}

Penulis melihat bahwa isu anak yang dilacurkan adalah sebuah isu yang sangat penting untuk dibahas, karena Anak sebagai penerus bangsa seharusya mendapatkan pendidikan, perkembangan dan pola asuh yang baik. Karena generasi merekalah yang selanjutnya akan meneruskan perjuangan kita. Namun, ironisnya keadaan ekonomi keluarga, rendahnya tingkat pendidikan dan kurangnya informasi membuat mereka terjebak dalam dunia pelacuran.

Dengan adanya UU No 23 Tahun 2002 tentang Perlindungan Anak serta Program Kesejahteraan Sosial Anak penulis harap mampu untuk mengatasi masalah sosial ini. Namun, pemerintah dalam mengimplementasikan kebijakannya juga harus memperhatikan masyarakat di wilayah pedesaan agar mereka juga mendapatkan informasi yang sama.

Upaya yang seharusnya dilakukan dalam mencegah dan mengurangi angka ESKA (Eksploitasi Seksual Komersial Anak) seharusnya bukan hanya kepada para masyarakat wilayah terpencil serta anak korban ESKA, namun juga para orangtua yang memiliki anak remaja. Karena penulis menganalisa bahwa seorang anak yang tidak mendapatkan pengakuan dan kurang akan rasa kasih saying serta kelekatan dengan orangtuaya dapat berpotensi untuk mencari apa yang dia butuhkan di tempat lain yang mungkin akan berdampak buruk kedepannya. Seperti hal yang terjadi pada Lisa (bukan nama sebenarnya) dalam contoh kasus pada pembahasan yang telah ditulis diatas.

Kasus yang ditampilkan di atas menunjukkan bahwa pelacuran anak tidak hanya menjadi bisnis para mucikari seperti yang selama ini nampak ke permukaan, tetapi juga karena kondisi psikologi, sosial, kultural, dan ekonomi keluarga.

Merosotnya kehidupan keluarga, bukan hanya karena faktor ekonomi tetapi juga karena faktor sosial dan kultural. Mereka ini hanya terlibat dalam kehidupan kerja, sehingga tidak sempat melakukan fungsi sebagai orang tua. Dengan demikian hubungan orang tua dan anak tidak lagi harmonis. Akibatnya anak mengalami keterasingan (eliminated), sehingga ia akan mencari jalan sendiri untuk memenuhi keinginan-keinginannya.

Sebagai calon pekerja sosial penulis melihat bahwa pekerja sosial memiliki andil dalam membantu mengurangi angka ESKA. Pekerja sosial dalam kasus ini berperan sebagai enabler, educator, fasilitator dan broker yang menghubungkan antara sistem sumber denga para klien yang membutuhkan.

\section{DAFTAR PUSTAKA}

Budiyawati, Hening. dkk. 2007. Analisis Situasi Eksploitasi Seksual Komersial terhadap Anak di

Semarang dan Sekitarnya. Yayasan Setara Kementrian Pemberdayaan Perempuan.

Clifford T. Morgan, et. al. 1986. Introduction to Psychology. New York: McGraw-Hill Inc. P. 473. 
George Boeree. 2008. Personality Theories: Melacak Kepribadian Anda Bersama Psikolog Dunia. Yogyakarta: Prismasophie. Hal. 74-78.

Garis Besar Konvensi ILO No. 182 mengenai PELARANGAN DAN TINDAKAN SEGERA UNTUK PENGHAPUSAN PEKERJAAN TERBURUK UNTUK ANAK.

Lansdown, Gerison. 2005. Innocent Insight The Evolving Capacities of the Child. Italy: Giuntina Florence.

Soetarso. 1996. Praktek Pekerjaan Sosial. Bandung: Sekolah Tinggi Kesejahteraan Sosial. Undang - Undang (UU) RI No.9 Tahun 2002 Konvensi Hak Anak.

Undang-Undang RI Nomor 23 Tahun 2003 tentang Perlindungan Anak.

Wibhawa, Budhi., Raharjo T., Budiarti, Meilany. 2010. Dasar-dasar Pekerjaan Sosial. Bandung: Widhya Padjadjaran.

Zastrow, Charles. 2010. Introduction to Social Work and Social Welfare, Tenth Edition. USA: PrePress PMG.

http://www.scribd.com/doc/90328027/PELACURAN-ANAK-REMAJA-DAN-AKIBATNYABAGI-MEREKA

http://www.merdeka.com/peristiwa/pelajar-smp-di-bandung-jadi-pelacur-cukup-dibayar-pakaipulsa.html

http://kapanjadibeda.wordpress.com/2014/03/17/eska-eksploitasi-seks-komersial-anak/ 